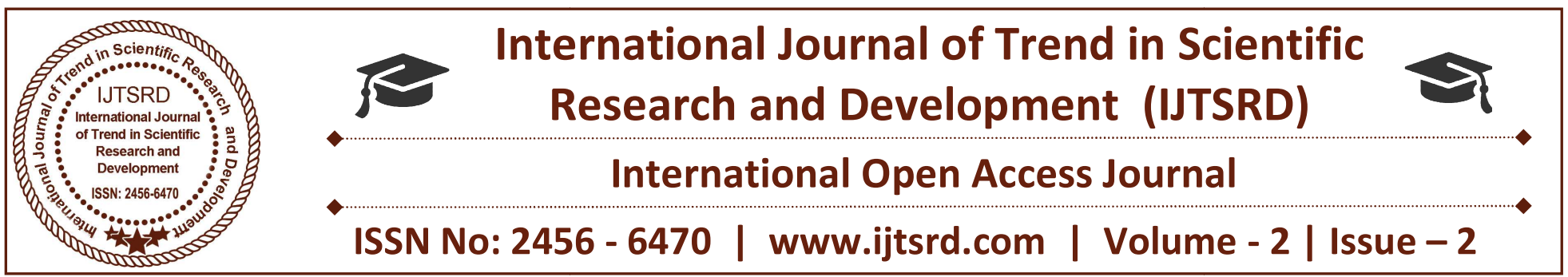

\title{
Availability and Internet Access in Homes through Bayesian Networks
}

\author{
Maria del Carmen Santos Pinacho, Guillermo De la Torre-Gea \\ University of Sierra Sur, Maxico
}

\begin{abstract}
Information and Communication Technologies (ICT) have been gaining importance for the economic, social and educational development of a given country that allows streamlining and streamlining various processes. However, there is still a disparity between households, regions, and people who access and do not access this technology, because there are problems of infrastructure, use, but above all, low income that does not allow access to the internet. This study is conducted regarding the availability and access to the internet in the homes of the municipality of Miahuatlán de Porfirio Díaz, with the objective of determining the relationship that exists between income in the home, characteristics of the home, provision of electrical and electronic appliances with internet coverage in homes. For this reason, data were taken from the Intercensal Survey 2015 conducted by the National Institute of Statistics and Geography and analyzed through the study of Bayesian networks with the Elvira program. It is concluded that income is highly related to access and not access to the internet, for the cost involved in having this technology, and to cover all the needs and services of the family in the home.
\end{abstract}

Keywords: Internet access, Characteristics of the home, income, services

\section{Introduction}

Nowadays, we are immersed in a society, in which, greater use is made of Information and Communication Technology (ICT). In this way, ICT has been considered tools for the development of individuals and societies since, they facilitate the handling of information by allowing it to be created, shared, improved, enriched and transformed into knowledge (INEGI, 2016).

Thus, Belloc (2012) points out that in the social dimension ICT includes the strength and influence it has in the fields and new social structures, producing a constant and bidirectional interaction between technology and society. In this way, ICTs have been gaining importance in everyday life, and academia, as well as in the public and private spaces, since their implementation has made it possible to improve, streamline and make efficient various processes, given the characteristics that ICTs present, In addition, they allow generating new forms of communication, knowledge, and accessibility of information.

One example of the boom that ICTs have had is the internet, which has been a tool that has facilitated the execution of procedures, services and processes, as mentioned by Botello (2015), pointing out that many of the activities that previously required physical presence, nowadays on the internet have been simplified through digitization. This is how there has been an increase in the need to have access to and use of the internet.

Although access to this medium is important, nowadays, not all people, or in homes, have the availability of this medium, since there are problems of infrastructure, socioeconomic, digital literacy, which refers to the problem of the digital gap. 
The digital divide was defined as the distance between individual, business, geographical areas, socioeconomic levels in relation to opportunities to access ICTs, as well as the use of the OECD Internet, 2001 (as cited in Espinoza, 2010). In the issue of access to the Internet, the difficulties that arise to access this technology is the physical availability referring to an adequate infrastructure and the cost involved in its development and maintenance, in addition, there are obstacles to support and training (García, nd).

However, Serrano and Martínez (2003) point out that the economic problems of the countries to offer the Internet service at suitable levels reflect that the digital divide derives from an economic gap, Thus, there is a relationship between Internet access and the economic prosperity of a country.

The existence of a digital divide in the country is reflected in the results of the National Survey on Availability and Use of Information Technologies in Homes, 2015, since with respect to the Internet connection, in the Federal District, Nuevo León, and Baja California Sur, the percentage of households with an Internet connection is approximately 60 percent, while in Guerrero, Tabasco, Oaxaca, and Chiapas, $20 \%$ of homes have a connection (INEGI, 2015). It is reflected that Oaxaca is one of the states that have less access to this service, therefore, it was important to determine Internet access in homes in the state of Oaxaca, particularly in the municipality of Miahuatlán de Porfirio Díaz, with relationship to income, characteristics of housing, and services in households.

\section{Method}

For the elaboration of this work, data were taken from the Intercensal Survey 2015 conducted by the National Institute of Statistics and Geography (INEGI), from which those that were interested in determining the access and availability of Internet access were taken. The survey was applied in households, therefore, the variables corresponding to characteristics of households, provision of services, electronic devices, household appliances and income were selected. In such a way that the variables to be considered were those that are available in Table 1:
Table 1: Variables analyzed in the study

\begin{tabular}{|l|l|}
\hline \multicolumn{1}{|c|}{ Analysis Groups } & \multicolumn{1}{|c|}{ Variables } \\
\hline $\begin{array}{l}\text { Characteristics of } \\
\text { the house and } \\
\text { inhabitants }\end{array}$ & $\begin{array}{l}\text { Type of wall, floors, ceiling, } \\
\text { number of people in the home. }\end{array}$ \\
\hline Services and tools & $\begin{array}{l}\text { Type of fuel, electricity, piped } \\
\text { water, shower, sanitary service, } \\
\text { drainage, own car, }\end{array}$ \\
\hline Appliances & $\begin{array}{l}\text { Air conditioning, refrigerator, } \\
\text { washing machine, oven, Stove }\end{array}$ \\
\hline Electronic devices & $\begin{array}{l}\text { television, computer, telephone, } \\
\text { cell phone, serv. }\end{array}$ \\
\hline Income & $\begin{array}{l}\text { Income in the home for work per } \\
\text { month. }\end{array}$ \\
\hline Technology & Internet \\
\hline
\end{tabular}

Source: Prepared based on data from the Intercensal Survey, 2015. Excerpted from

The analysis and study of each one of the variables considered was done through the Elvira software, which has its own format for coding models, a reader that interprets the coded models, a graphical interface that allows the construction of networks, what is intended for the edition and evaluation of probabilistic graphics models, specifically, Bayesian networks and flow diagrams (Ramírez-Madrigal, 2018; RenteríaGaeta, 2018; De la Torre-Gea et al., 2016).

The Bayesian networks (BNs) for Ropero (2014) are a statistical tool applied in environments under conditions of uncertainty. For this reason, Uusitalo 2007 (as cited in Ropero et al., 2014) in this tool the most used solution is the discretization of the variables since this process involves the loss of statistical information by reducing it to the accuracy and precision in the resulting model.

For this reason, one of the advantages of this type of network is that they simultaneously represent both the qualitative and quantitative dimensions of a problem Aguilera, Fernández, Fernández, Rumí, and Salmerón, Edwards, 1998, Heckerman, 1995 (as cited in López, 2012). In addition, Bayesian networks identify interaction effects and models of nonlinear relationships between variables, likewise, it makes bidirectional inferences, that is, it goes from causes too, and from these to its causes, it also makes abductive inferences to determine explanations of a phenomenon based on a set of Gámez and Huete evidence (as cited in López, 2012). In this way, the relationships between the five analysis groups and the internet access in the homes of Miahuatlán de Porfirio 
International Journal of Trend in Scientific Research and Development (IJTSRD) ISSN: 2456-6470

Díaz were determined, which are described in the following section.

\section{Results}

To understand the information presented in table 2, each of these variables is described according to the relationships obtained once the Bayesian network was made, and to have made the respective analysis of the incident tables, highlighting that the degree of relationship was first visualized of the nodes of the network, by identifying the color, and direction of the generated arrows.

Table 2: Description of a priori probability and posterior probability of variables analyzed

\begin{tabular}{|c|c|c|c|}
\hline Variable & Description & $\begin{array}{l}\text { Probability } \\
\text { (a priori) }\end{array}$ & $\begin{array}{l}\text { Probability } \\
\text { (a posteriori) }\end{array}$ \\
\hline WALLS & $\begin{array}{l}\text { Wall of partition, brick, block, stone, quarry, cement } \\
\text { or concrete. }\end{array}$ & $76 \%$ & $98 \%$ \\
\hline CEILINGS & Ceiling of concrete slab or joists with vault & $56 \%$ & $100 \%$ \\
\hline FLOORS & Cement or firm floor & $80 \%$ & $89 \%$ \\
\hline $\begin{array}{l}\text { NUMBER OF } \\
\text { PEOPLE IN THE } \\
\text { HOME }\end{array}$ & How many live in the house? & $\begin{array}{l}22 \% \text { live } \\
4 \text { people }\end{array}$ & $22 \%$ \\
\hline GAS & 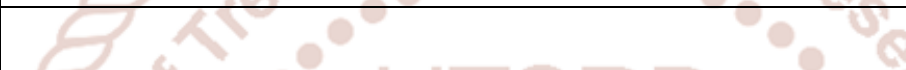 & $49 \%$ & $65 \%$ \\
\hline STOVE & \begin{tabular}{|l|l|} 
The fuel is gas \\
\end{tabular} & $93 \%$ & $95 \%$ \\
\hline ELECTRICITY & Does the house have a stove? & $98 \%$ & $99 \%$ \\
\hline TUBING WATER & Yes, there is light in the house & $52 \%$ & $50 \%$ \\
\hline WATERING CAN & Water is obtained from a community well ntiflic & $63 \%$ & $51 \%$ \\
\hline AIR CONDITIONER & The house does not have a shower hand & $98 \%$ & $98 \%$ \\
\hline $\begin{array}{l}\text { SANITARY } \\
\text { SERVICE }\end{array}$ & The house does not have air conditioning & $65 \%$ & $74 \%$ \\
\hline SEWER SYSTEM & The house has (toilet) & $43 \%$ & $56 \%$ \\
\hline FRIDGE & Is the drain connected to the public network? & $63 \%$ & $71 \%$ \\
\hline $\begin{array}{l}\text { WASHING } \\
\text { MACHINE }\end{array}$ & Does the house have a refrigerator? & $66 \%$ & $61 \%$ \\
\hline OVEN & The house does not have a washing machine & $82 \%$ & $79 \%$ \\
\hline TV & The house does not have an oven & $76 \%$ & $85 \%$ \\
\hline COMPUTER & Does the house have a television? & $81 \%$ & $76 \%$ \\
\hline PHONE & Does not the house have a computer? & $88 \%$ & $85 \%$ \\
\hline CELL PHONE & The house does not have a telephone line & $69 \%$ & $73 \%$ \\
\hline SERV. OF TV. PAY & In the house they have a cell phone & $82 \%$ & $80 \%$ \\
\hline OWN CAR & The house does not have pay television service & $71 \%$ & $69 \%$ \\
\hline $\begin{array}{l}\text { INCOME PER } \\
\text { MONTH FOR } \\
\text { WORK IN THE } \\
\text { HOME }\end{array}$ & The house does not have its own car & $\begin{array}{l}26 \% \text { income } \\
\text { less than } \\
3000.00\end{array}$ & $24 \%$ \\
\hline INTERNET & $\begin{array}{l}\text { How much is the income per job per month in the } \\
\text { home? }\end{array}$ & $87 \%$ & $84 \%$ \\
\hline
\end{tabular}


Subsequently, the analysis of the incidence tabs was performed, according to the relationships obtained in the first step, since in the second stage the a priori probability of each of the variables is identified, as well as the a posteriori probability that can be identified as change or interrelate a given variable that another one has or has happened.

Figure 1: Bayesian network Internet access in homes of Miahuatlán de Porfirio Diaz 2015.

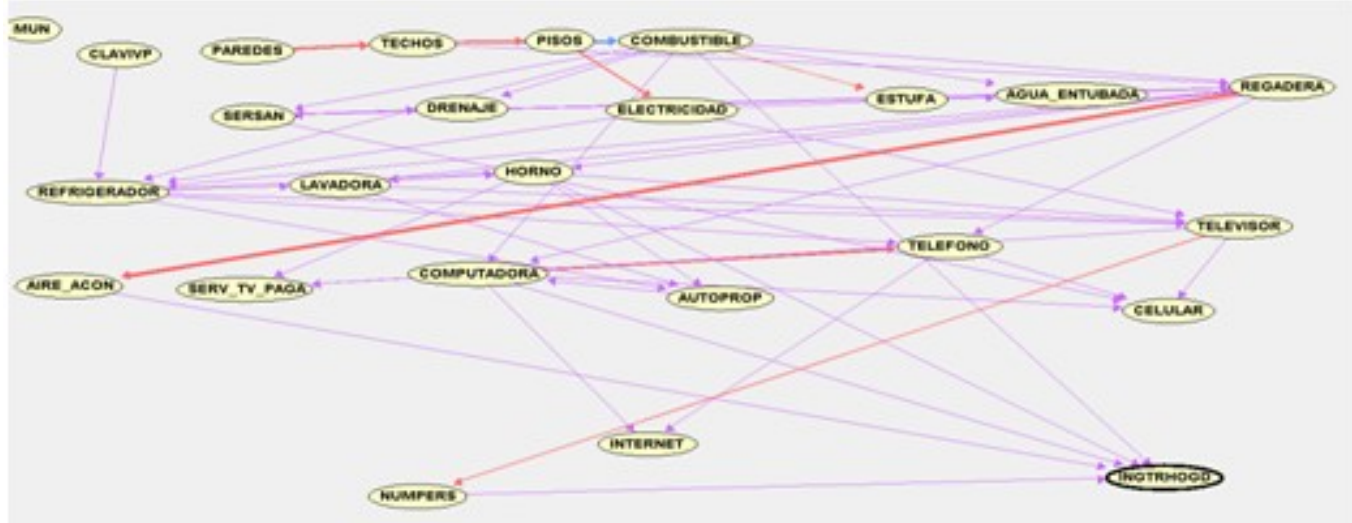

Figure 1 shows the relationship between each of the variables analyzed, highlighting that the variable that has the greatest relationship with the other variables is income, which corresponds to $26 \%$ of households that receive income of fewer than 3000 pesos, that is, based on this variable and its respective percentage, depends on the services, tools, characteristics of the home.

In this way, it is observed that the income will depend in turn on the variable n.- of people in the household, which, in this case, according to the a priori priority corresponds to a total of approximately 4 people in the household ( $22 \%$ ). Another dependent variable is fuel, indicating that, according to the survey and the $a$ priori probability obtained, $49 \%$ of homes use gas fuel, having a strong relationship with stove disposal in the home $(93 \%)$.
Thus, income has a fundamental role for access to technology, since in this study it was determined that there is a relationship when a home has or does not have a computer in the home, telephone, cell phone, and internet. On the other hand, another of the variables that are closely related are the characteristics of the home with the services available and the type of fuel used.

Therefore, the rest of services and tools such as drainage, furnace, television, air conditioning and car, occupy a focus and relationship once the other variables have been met, mainly in the case of electricity. However, in order to understand the relationships better and more accurately, the analysis of the incidence tables with the a posteriori probability determination is presented below.

Figure 2: Bayesian network Internet access in homes of Miahuatlán de Porfirio Diaz 2015.

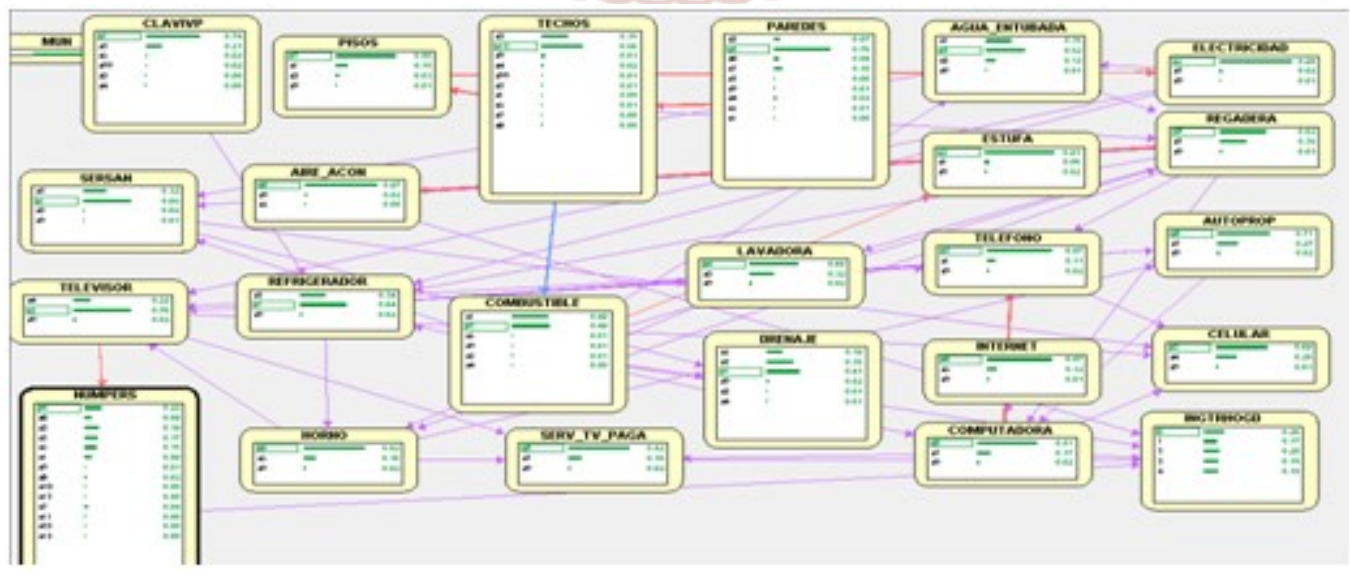


Figure 3: Incidence tables. Probability a posteriori

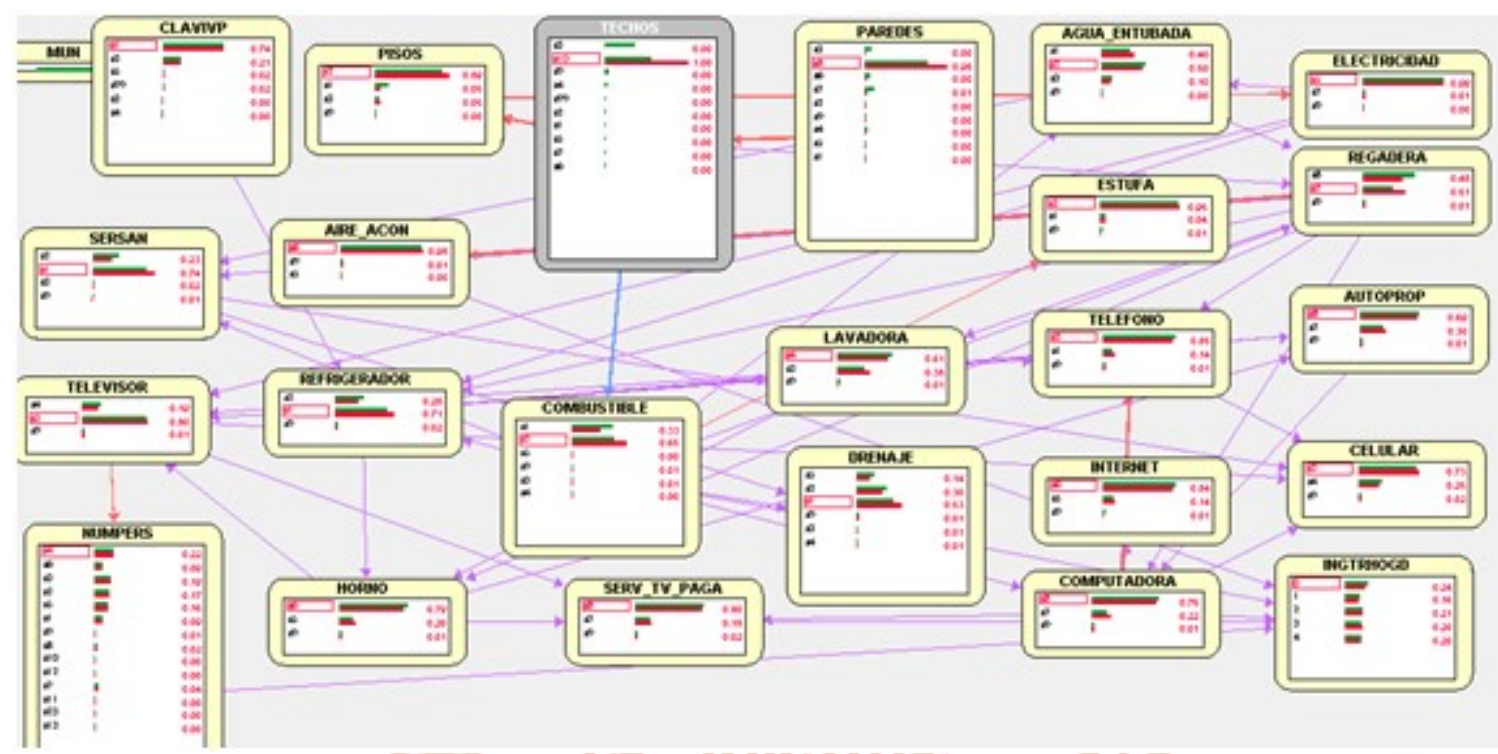

Once the a posteriori probability analysis was carried out, the following results were obtained, for the first group of variables called housing characteristics and inhabitants it is obtained that they are closely related to each other, however, only one of them maintains a lower relation with the combustible variable since if the roof is concrete $(100 \%)$ there is a greater probability that the house uses gas fuel at $65 \%$, that is, better housing conditions are present when having cement floors (89\%) ) and partition walls (98\%).

Therefore, this generates a lower probability of not having access to the internet, since $84 \%$ of households in this situation would not have access to this technology, however, this figure is still worrisome, because approximately only $20 \%$ of households would continue with this service, which the node (internet) is reflected in the third stratum, corresponding to households that obtain more than \$ 3000.00 monthly access.

For the second group of variables corresponding to services and tools, the only ones that are taken with greater importance are fuel, water, electricity, and sanitation, since the fuel is related to other variables such as the computer, income and housing characteristics. (floors). This reflects that some of these services require allocating part of the income received per month. However, the other variables are not related to Internet access, since they comply with the complementary function of condition and characteristics of the home.

In the groups of household electrical appliances and electronic, for the first case, they are not fundamental in the access to Internet since they are nondeterminant variables, whereas the electronic devices if they present too much relation, because in the tables it is reflected that there is a probability a priori that it is necessary to have a computer, to access the internet, which, in this case, having $76 \%$ of the population that does not have this equipment, will not access Internet technology. Thus, not having a computer means that households receive an income of less than 3000 and, therefore, do not have the resources to be part of the stratum of the population that can afford access to the Internet. The same happens with the provision of a cell phone or a landline.

\section{Conclusion}

Once analyzed the variables selected for the determination of Internet access in homes 2015, it concludes the following: Internet access continues to be a privilege for those who have this technology, because revenues are crucial to cover the costs of infrastructure, installation, and maintenance, this was reflected in the fact that in households that had low income did not have a computer, did not have telephone line, or pay TV services and therefore did not have Internet access in the home. The above can be determined that to use and have these appliances and services in the home requires that they are making constant payments (rent) which would generate the monthly income of the household, that is, stop covering other needs such as food, education among others to correct this expense, in addition, if it is considered that most of the households receive a low income, it is really impossible to allocate a certain percentage to be part of this new era of the 
information society and technology. This is how it is important to implement various actions to improve and increase Internet access in different households, at this point, it is necessary to mention that since the income variable has the greatest influence on the disposition of this, it is not enough to generate programs or access policies, but also take into account maintenance, and installation. On the other hand, the provision of electronic devices such as computers, telephones, and cell phones are also important for households to access the benefits of the Internet since these are some of the instruments needed to use this technology. Likewise, it is concluded that the characteristics of the dwelling have a minimal relationship with access to the internet because not all the variables considered influencing this technology.

\section{REFERENCES}

1. Belloch, C. (2012). Las Tecnologías de la Información y Comunicación en el aprendizaje. Material docente [on-line]. Departamento de Métodos de Investigación y Diagnóstico en Educación. Universidad de Valencia.

2. Instituto Nacional de Estadística y Geografía (2015). Encuesta Intercensal,2015. México: INEGI.

3. Instituto Nacional de Estadística y Geografía (2016). Estadísticas a propósito del día mundial de internet. México: INEGI. Instituto Nacional de Estadística y Geografía (2015). Encuesta nacional sobre disponibilidad y uso de tecnologías de la información en los hogares, 2015. México: INEGI.

4. Naciones Unidas (2005). Indicadores clave de las tecnologías de la información y de las comunicaciones Partnership para la medición de las TIC para el desarrollo. Naciones Unidas: Santiago de Chile.

5. Serrano, Santoyo A. y Martínez, Martínez E. (2003). La brecha digital mitos y realidades. Universidad Autónoma de Baja California: Creative Commons.

6. De la Torre-Gea, G., Delfín-Santisteban, O., Torres-Pacheco, I., Soto-Zarazúa, G., GuevaraGonzález, R., Rico-García, E. (2014). Redes Bayesianas aplicadas a un modelo CFD del entorno de un cultivo en invernadero. Agrociencia, 48(3): 307 - 319.
7. López Puga J. (2012). Cómo Construir y Validar Redes Bayesianas con Netica. Revista Electrónica de Metodología Aplicada. 17 (1). 1-17.

8. Espinoza N. (agosto 2010). La brecha digital. Avances para su superación en Venezuela: Revista Iberoamericana de Ciencia, Tecnología y Sociedad. P.1-16

9. Ramírez-Madrigal, C., De la Torre-Gea, G. (2018). PERCEPTION OF SECURITY IN MEXICO THROUGH BAYESIAN NETWORKS. International Journal of Trend in Scientific Research and Development, 2(2): 1244 $-1252$.

10. Rentería-Gaeta, R., De la Torre-Gea, G. (2018). Bayesian analysis of internet access through apps as an e-government development strategy in Mexico. International Journal of Trend in Scientific Research and Development, 2(2): 1070 $-1074$

11. Ropero, R. F., Aguilera, P.A. Fernández, A., Rumí (febrero, 2014). Redes bayesianas: una herramienta probabilística en los modelos de distribución de especies. Ecosistemas 23(1), 5460 .

12. Botello, Peñaloza H. A. (julio- diciembre, 2015). Determinantes del acceso al internet: Evidencia de los hogares del Ecuador. Entramado 11(2), 12-19.

13. García Gómez F. J. (n.d.) brecha digital, brecha social, brecha económica, brecha cultural: la biblioteca pública ante las cuatro caras de una misma moneda. España: Bibliotecas públicas a la vanguardia revista de opinión para el desarrollo de las bibliotecas públicas. 